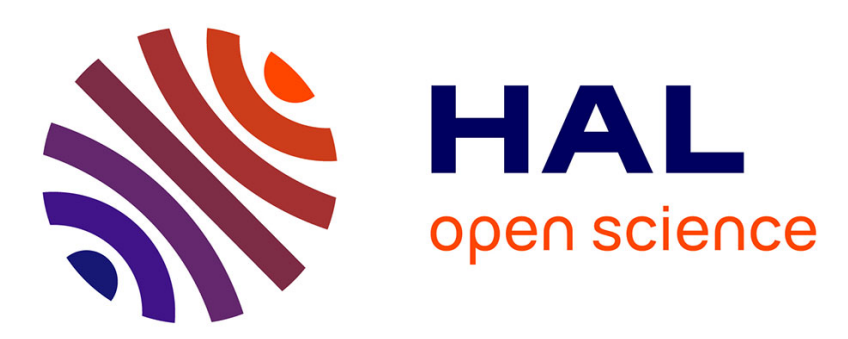

\title{
Classification of Optical Technologies for the Mapping of Production Environments
}

\author{
Marius Greger, Daniel Palm, Louis Louw, Konrad Von Leipzig
}

\section{To cite this version:}

Marius Greger, Daniel Palm, Louis Louw, Konrad Von Leipzig. Classification of Optical Technologies for the Mapping of Production Environments. IFIP International Conference on Advances in Production Management Systems (APMS), Sep 2019, Austin, TX, United States. pp.197-205, 10.1007/9783-030-30000-5_26. hal-02458391

\section{HAL Id: hal-02458391 \\ https://hal.inria.fr/hal-02458391}

Submitted on 28 Jan 2020

HAL is a multi-disciplinary open access archive for the deposit and dissemination of scientific research documents, whether they are published or not. The documents may come from teaching and research institutions in France or abroad, or from public or private research centers.
L'archive ouverte pluridisciplinaire HAL, est destinée au dépôt et à la diffusion de documents scientifiques de niveau recherche, publiés ou non, émanant des établissements d'enseignement et de recherche français ou étrangers, des laboratoires publics ou privés. 


\title{
Classification of optical technologies for the mapping of production environments
}

\author{
Marius Greger ${ }^{1}$, Daniel Palm ${ }^{10000-0003-1485-8078]}$, Louis Louw2 [0000-0001-9789-5661], \\ Konrad von Leipzig ${ }^{2}$ \\ ${ }^{1}$ ESB Business School, Reutlingen University, Alteburgstr. 150, 72762 Reutlingen, Germany \\ ${ }^{2}$ Department of Industrial Engineering, University of Stellenbosch, 145 Banghoek Rd., 7600 \\ Stellenbosch, South Africa \\ daniel.palmereutlingen-university.de
}

\begin{abstract}
Indoor localization systems are becoming more and more important with the digitalization of the industrial sector. Sensor data such as the current position of machines, transport vehicles, goods or tools represent an essential component of cyber-physical production systems (CCPS). However, due to the high costs of these sensors, they are not widespread and are used mainly in special scenarios. However, especially optical indoor positioning systems (OIPS) based on cameras have certain advantages due to their technological specifications. In this paper, the application scenarios and requirements as well as their characteristics are presented and a classification approach of OIPS is introduced.
\end{abstract}

Keywords: Optical Indoor Localization Systems, Cameras, Marker-based Tracking, changeable and reconfigurable manufacturing.

\section{$1 \quad$ Introduction}

In order to meet the requirements of Industry 4.0, a high degree of adaptability of production systems is required [1]. In this context, there is a focus on the so-called smart factory, in which people, machines, objects and products are intelligently linked with each other through the provision of hardware and software. This enables increasing automation and autonomous reaction to unpredictable events. [2]

For this purpose, embedded systems are integrated into objects, devices, buildings, forklifts as well as into production facilities and logistics components, whereby these become cyber-physical systems (CPS). These systems, also known as intelligent objects, can then autonomously and decentrally communicate with each other and optimize themselves. The result is a virtual image of reality, which is continuously updated with the help of real-time data. [3]

Westkämper $[4,5]$ considers the ability to unambiguously identify and localize objects and the individuality of systems, processes, objects and products as well as the controllability of the increasing complexity to be particularly important. Indoor positioning systems (IPS) are architectures of tags, location sensors, a locating engine and a locating application that can be used to determine the position of a person or an object 
in buildings [6]. Tags are used as spatial reference points or for unambiguous identification and the location sensor provides ID and position values. The location engine uses this data to derive the actual position of the specific location object. The location application is the software solution for further processing the position data [7].

Positioning can be relative or absolute. The relative positioning determines the position of the location object relative to a reference point. In absolute position determination, the position is specified in a global coordinate system [8]. A variety of systems and technologies using different algorithms, techniques and technologies are available for the unambiguous identification and localization of objects, which differ in their degree of maturity and their performance [9-11]. Due to the high cost of these systems, they are actually only applied in a limited amount of scenarios, such as the navigation of autonomous transport vehicles [12]. In particular, optical indoor positioning systems (OIPS), which use cameras or other optical sensors to determine the position of localization objects in their field of view, [13, 14], have proven to be precise and robust in industrial applications [15-17]. Compared to radio-based approaches, which have also gained popularity, they are not influenced by reflections on metal, multipath propagation, interferences, scattering or absorption by liquids [18]. They are highly scalable and can work with tags that can be printed by the user inexpensively, or even without any tags. Therefore, they seem to be especially promising for the application within small and medium sized enterprises (SME).

\section{Characteristics and Requirements of Indoor Location Systems}

The wide field of application of indoor localization systems leads to a multitude of requirements. An overview of requirements mentioned in literature is given in Table 1. The authors have been assigned to the requirements mentioned in their works.

Table 1. Identified requirements towards indoor positioning systems (IPS)

\begin{tabular}{|c|c|c|c|c|c|c|}
\hline Author & $\begin{array}{l}\text { Günthner } \\
\text { et.al.[19] }\end{array}$ & $\begin{array}{c}\text { Hohenstein } \\
{[6]}\end{array}$ & $\begin{array}{c}\text { Mautz } \\
{[18]}\end{array}$ & $\begin{array}{c}\text { Liu et.al. } \\
\text { [20] }\end{array}$ & Han [21] & Malik [7] \\
\hline \multicolumn{7}{|c|}{ Localization function } \\
\hline Continuity & & $\mathrm{x}$ & $\mathrm{x}$ & & & $\mathrm{x}$ \\
\hline Output data & & $\mathrm{x}$ & $\mathrm{x}$ & & & $\mathrm{x}$ \\
\hline Required infrastructure & & $\mathrm{x}$ & $\mathrm{x}$ & & & $\mathrm{x}$ \\
\hline \multicolumn{7}{|c|}{ Localization performance } \\
\hline Accuracy & $\mathrm{x}$ & $\mathrm{x}$ & $\mathrm{x}$ & $\mathrm{x}$ & $\mathrm{x}$ & \\
\hline Coverage & $\mathrm{x}$ & $\mathrm{x}$ & & $\mathrm{x}$ & $\mathrm{x}$ & \\
\hline Repeat accuracy & $\mathrm{x}$ & & $\mathrm{x}$ & & & \\
\hline Update rate & $\mathrm{x}$ & $\mathrm{x}$ & & $\mathrm{x}$ & $\mathrm{x}$ & \\
\hline \multicolumn{7}{|c|}{ Overall system } \\
\hline Scalability & $\mathrm{x}$ & $\mathrm{x}$ & $\mathrm{x}$ & $\mathrm{x}$ & $\mathrm{x}$ & $\mathrm{x}$ \\
\hline Availability & & & $\mathrm{x}$ & & & \\
\hline Robustness & $\mathrm{x}$ & $\mathrm{x}$ & $\mathrm{x}$ & $\mathrm{x}$ & & $\mathrm{x}$ \\
\hline
\end{tabular}


In the following section, a short description of the requirements is provided.

- Continuity refers to the ability of a system to repeat a certain function in time and space. An IPS is continuous if position determination is not limited to a few predefined measurements [6].

- Output data refers to the location data provided by an IPS, e.g. 2D or 3D coordinates, orientation, ID, etc.

- Required infrastructure refers to the infrastructure needed for position determination that goes beyond the location sensor and the location engine. Mautz [18] distinguishes between OIPS with or without markers.

- Accuracy refers to a numerical measure in a given metric unit and results from the deviation between nominal and actual position.

- Coverage refers to the maximum range between an IPS and a location object, in which the object can still be identified and its position be determined.

- Repeat accuracy or precision, describes the repeatability of a measurement result, given that the measurement is carried out under the same conditions.

- Update rate refers to the frequency at which the position data can be determined by a system. An important aspect of the update rate is the latency, which is the time required by a system to determine the actual position of a localization object.

- Scalability refers to the achievable number of localizable objects and structures.

- Availability refers to the amount of time a system is available for use with the required accuracy and integrity.

- Robustness refers to the resistance towards unwanted influences of a system, e.g. changes in temperature, reflections, occlusion, etc.

- Architecture refers to the fact that systems can be realized in a way that the localization system is attached to the localization object, the position data are thus recorded directly at the object to be located (inside-out). In contrast to this approach in an outside-in approach, the localization system is attached to the infrastructure. [6]

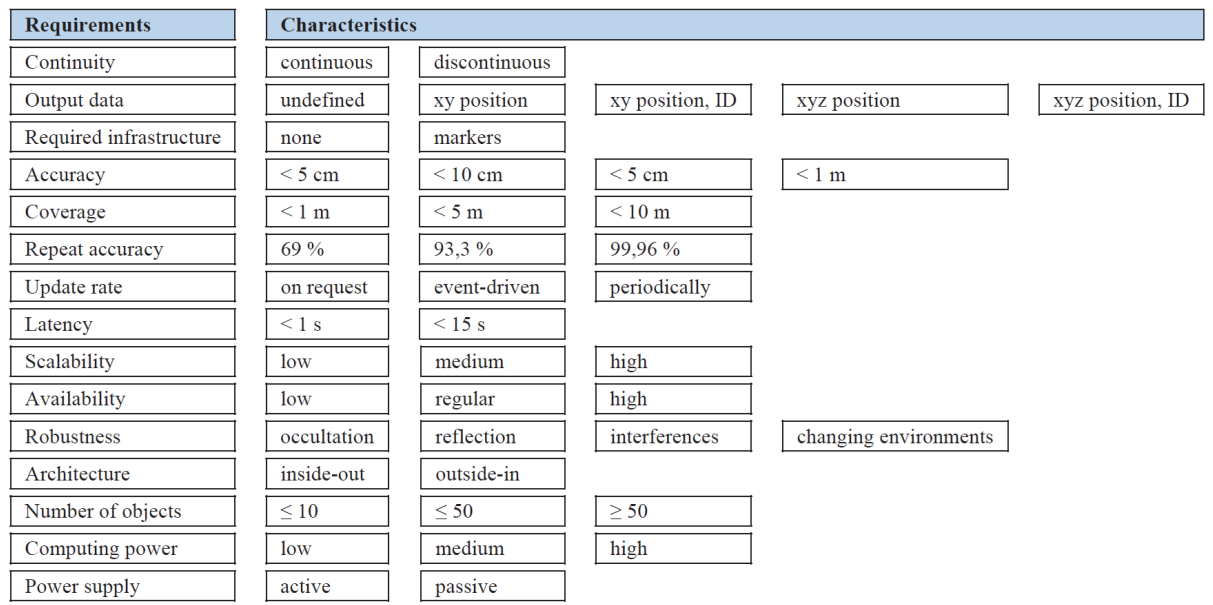

Fig. 1. Requirements towards indoor positioning systems (IPS) and their characteristics 
Moreover, the number of localization objects, the required computing power and power supply are important aspects, as they influence the costs and the components of a system. Based on a literature review (see e.g. $[16,18,22,23,6]$ ), the characteristics of the requirements were determined. The results are shown in Figure 1.

\section{Application scenarios of OIPS}

After the introduction of the requirements for OIPS in section 2, this section presents various application scenarios explored in the literature and clustered according to their main application area. A short description of the application scenario is given (see Table 2 and Table 3). The list of scenarios represents the use cases mentioned in literature. The objective of the collection was not so much absolute completeness, but rather a representative selection, which makes it possible to assign the application scenarios to basic system configurations in the following section.

Table 2. Application scenarios of optical indoor positioning systems (OIPS) in Logistics

\begin{tabular}{|c|c|c|}
\hline Area & Application scenario & Description \\
\hline \multirow{10}{*}{ 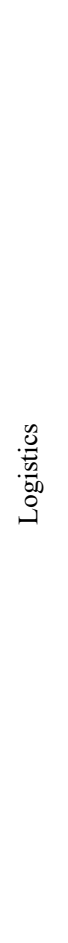 } & $\begin{array}{l}\text { Automatic goods recog- } \\
\text { nition at arrival }\end{array}$ & $\begin{array}{l}\text { Delivered goods can be automatically identified and posted directly } \\
\text { at the arrival. [17] }\end{array}$ \\
\hline & Component search & $\begin{array}{l}\text { Comprehensive localization of components and intermediate prod- } \\
\text { ucts. [27] }\end{array}$ \\
\hline & Intelligent tool control & $\begin{array}{l}\text { Through the localization of tools and the intelligent analysis of this } \\
\text { data, it is possible to determine and optimize the utilization. }[27,28]\end{array}$ \\
\hline & Inventory management & $\begin{array}{l}\text { Stocks are often unnecessarily increased because the storage location } \\
\text { or filling level of containers cannot be determined. [24] }\end{array}$ \\
\hline & $\begin{array}{l}\text { Navigation and locali- } \\
\text { zation of mobile robots }\end{array}$ & $\begin{array}{l}\text { Equipped with an RTLS, mobile robots can find their way around in } \\
\text { industrial environments. The determination of their absolute position } \\
\text { at any time is crucial for optimal navigation. [26] }\end{array}$ \\
\hline & Optimization of routes & $\begin{array}{l}\text { Optimization of in-house transport routes to avoid empty runs and } \\
\text { traffic jams. }\end{array}$ \\
\hline & Quality management & $\begin{array}{l}\text { Reduction of picking errors, packed goods are counted and compared } \\
\text { with the packing list. }[17,24]\end{array}$ \\
\hline & Route inspection & $\begin{array}{l}\text { Before a transport process is started, the system checks whether the } \\
\text { route is blocked or not. }\end{array}$ \\
\hline & $\begin{array}{l}\text { Tracking of intralogis- } \\
\text { tics transport vehicles }\end{array}$ & $\begin{array}{l}\text { Current position determination of transport vehicles (e.g. forklifts, } \\
\text { tugger trains) and their status. Optimization of availability, assign- } \\
\text { ment, routes and transparency. [24] }\end{array}$ \\
\hline & $\begin{array}{l}\text { Tracking of material } \\
\text { flows, load carriers or } \\
\text { workpieces }\end{array}$ & $\begin{array}{l}\text { Material movements can be recorded with Real-Time Locating Sys- } \\
\text { tems (RTLS) and passed on to higher-level system for analysis pur- } \\
\text { poses and process optimisation. }[6,24,25]\end{array}$ \\
\hline
\end{tabular}


Table 3. Application scenarios of optical indoor positioning systems (OIPS) in Production and Production-related Areas

\begin{tabular}{|c|c|c|}
\hline Area & Application scenario & Description \\
\hline \multirow{5}{*}{ 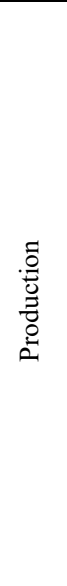 } & $\begin{array}{l}\text { Automation in production } \\
\text { lines }\end{array}$ & $\begin{array}{l}\text { The position data of work pieces or containers are used to improve } \\
\text { automation in transportation and feeding processes avoiding delays in } \\
\text { the production process. [27] }\end{array}$ \\
\hline & $\begin{array}{l}\text { Digital twin of factory, } \\
\text { layout of the production } \\
\text { system }\end{array}$ & $\begin{array}{l}\text { Creation of the digital twin of the production system. The constant po- } \\
\text { sition determination of machines and vehicles enables the digital rep- } \\
\text { resentation of the physical production system and the proactive recon- } \\
\text { figuration of production systems. This information plays a decisive } \\
\text { role especially in the case of increasing automation or even the intro- } \\
\text { duction of autonomous system components. [27] }\end{array}$ \\
\hline & Intelligent tool control & $\begin{array}{l}\text { Depending on the position of a tool (e.g. a screwdriver) relative to a } \\
\text { work piece to be machined, its control is automatically enabled. For } \\
\text { instance the torque is adjusted depending on the tool position. [24] }\end{array}$ \\
\hline & Operational optimization & $\begin{array}{l}\text { The position determination of every single batch, tool and employee } \\
\text { enables extensive process optimization by means of analysis. [28] }\end{array}$ \\
\hline & Quality management & Observation and reduction of assembly errors, [24] \\
\hline \multirow{3}{*}{ 忌 } & Access control & Monitoring of safety areas, increasing workplace safety. $[24,27]$ \\
\hline & Anti-theft protection & Continuous presence check, inspection of a known object. [18] \\
\hline & Evacuation management & $\begin{array}{l}\text { In emergencies (e.g. fire, release of dangerous substances, danger of } \\
\text { terrorism, etc.) companies must be able to determine whether employ- } \\
\text { ees are still in the building and ideally in which areas. [29] }\end{array}$ \\
\hline
\end{tabular}

\section{Classification of OIPS}

The biggest challenge for (potential) users is the fundamental definition of the architecture and identification method of the overall system. While the technological capabilities of individual components can easily be adapted on the basis of the specific requirements of the scenarios, the decision whether the camera system is located on the object to be localized or not and if a marker-based system or a non-marker based like a feature-based-tracking system should be used. Therefore, four classes were formed based on their characteristics (see Table 4) and the application scenarios are evaluated to determine, which of these classes could be used to implement the respective scenario (see Table 5).

Table 4. OIPS-classes based on architecture and infrastructure

\begin{tabular}{|l|l|l|}
\hline Class & Architecture & Required infrastructure \\
\hline OIPS Class 1 & outside-in & markers \\
\hline OIPS Class 2 & outside-in & none \\
\hline OIPS Class 3 & inside-out & markers \\
\hline OIPS Class 4 & inside-out & none \\
\hline
\end{tabular}


The results show that the outside-in architecture where the localization system is attached to the infrastructure (Class 1 and 2) covers a significantly wider range of scenarios than the inside-out architecture. In practice, this gives an initial indication of a technology to be introduced if the concrete application is still unspecified. All scenarios except the self-navigation of mobile robots can be solved with the outside-in architecture. For a detailed specification, further aspects of Figure 1 have to be considered.

Table 5. Classification of optical indoor positioning system (OIPS)-scenarios

\begin{tabular}{|c|c|c|c|c|}
\hline Scenario & $\begin{array}{l}\text { OIPS } \\
\text { Class } 1\end{array}$ & $\begin{array}{l}\text { OIPS } \\
\text { Class } 2\end{array}$ & $\begin{array}{l}\text { OIPS } \\
\text { Class } 3\end{array}$ & $\begin{array}{l}\text { OIPS } \\
\text { Class } 4\end{array}$ \\
\hline Access control & $\mathrm{x}$ & $\mathrm{x}$ & & \\
\hline Anti-theft protection & & $\mathrm{x}$ & & $\mathrm{x}$ \\
\hline Automatic goods recognition at arrival & $\mathrm{x}$ & & & \\
\hline Automation in production lines & $\mathrm{x}$ & $\mathrm{x}$ & & \\
\hline Component search & $\mathrm{x}$ & $\mathrm{x}$ & & \\
\hline Digital twin of factory & $\mathrm{x}$ & $\mathrm{x}$ & $\mathrm{x}$ & $\mathrm{x}$ \\
\hline Identification workplace & $\mathrm{x}$ & $\mathrm{x}$ & & \\
\hline Intelligent tool control & & $\mathrm{x}$ & & $\mathrm{x}$ \\
\hline Inventory management & $\mathrm{x}$ & & & \\
\hline Navigation and localization of mobile robots & & & $\mathrm{x}$ & $\mathrm{x}$ \\
\hline Operation optimization & $\mathrm{x}$ & $\mathrm{x}$ & & \\
\hline Optimization of routes & $\mathrm{x}$ & $\mathrm{x}$ & $\mathrm{x}$ & $\mathrm{x}$ \\
\hline Quality assurance (reduction of picking errors) & $\mathrm{x}$ & & & \\
\hline Route inspection & & $\mathrm{x}$ & & \\
\hline Tracking of intralogistics transport vehicles & $\mathrm{x}$ & & $\mathrm{x}$ & \\
\hline Tracking of material flows, load carriers or workpieces & $\mathrm{x}$ & $\mathrm{x}$ & & \\
\hline Number of viable scenarios & 12 & 11 & 4 & 5 \\
\hline
\end{tabular}

The minimum specification of an OIPS that can meet the requirements of all the scenarios listed in Class 1 must have an accuracy of better than $5 \mathrm{~cm}$, a coverage of at least 10 meter, a frame rate of more than 15 frames per second (fps) to track moving objects, a periodic update rate, a latency of under 1 second, a high scalability, the ability to identify more than 50 objects, and use an active power supply. This gives users an indication how to set up an OIPS with a maximum of flexibility in relation to the scenarios. Individual application requirements of each scenario are shown in Figure 2.

\section{$5 \quad$ Summary and Conclusion}

In this paper, the literature in regard to IPS and OIPS was analyzed and application scenarios as well as their requirements and characteristics were derived. The classification framework can be used by practitioners to determine the technical requirements to realize a specific application scenario. It was shown that OIPS is a relevant technology that can cover a wide range of scenarios and that an outside-in architecture with localization system attached to the infrastructure (mounted set of cameras and marker- or non-marker-based identification and localization of the objects) covers a significant 
higher range of scenarios in the production environment that the inside-out architecture. Here it could be proven that this architecture has the broader application possibilities.

The high proportion of low-cost computing power and image sensor chips on the market make cost-effective positioning solutions that can meet the requirements more attractive for a wider range of scenarios. This in combination with the possibility to paper-print a marker for identification purposes for literally no costs, opens up a costefficient realization of high number of scenarios presented and characterized.

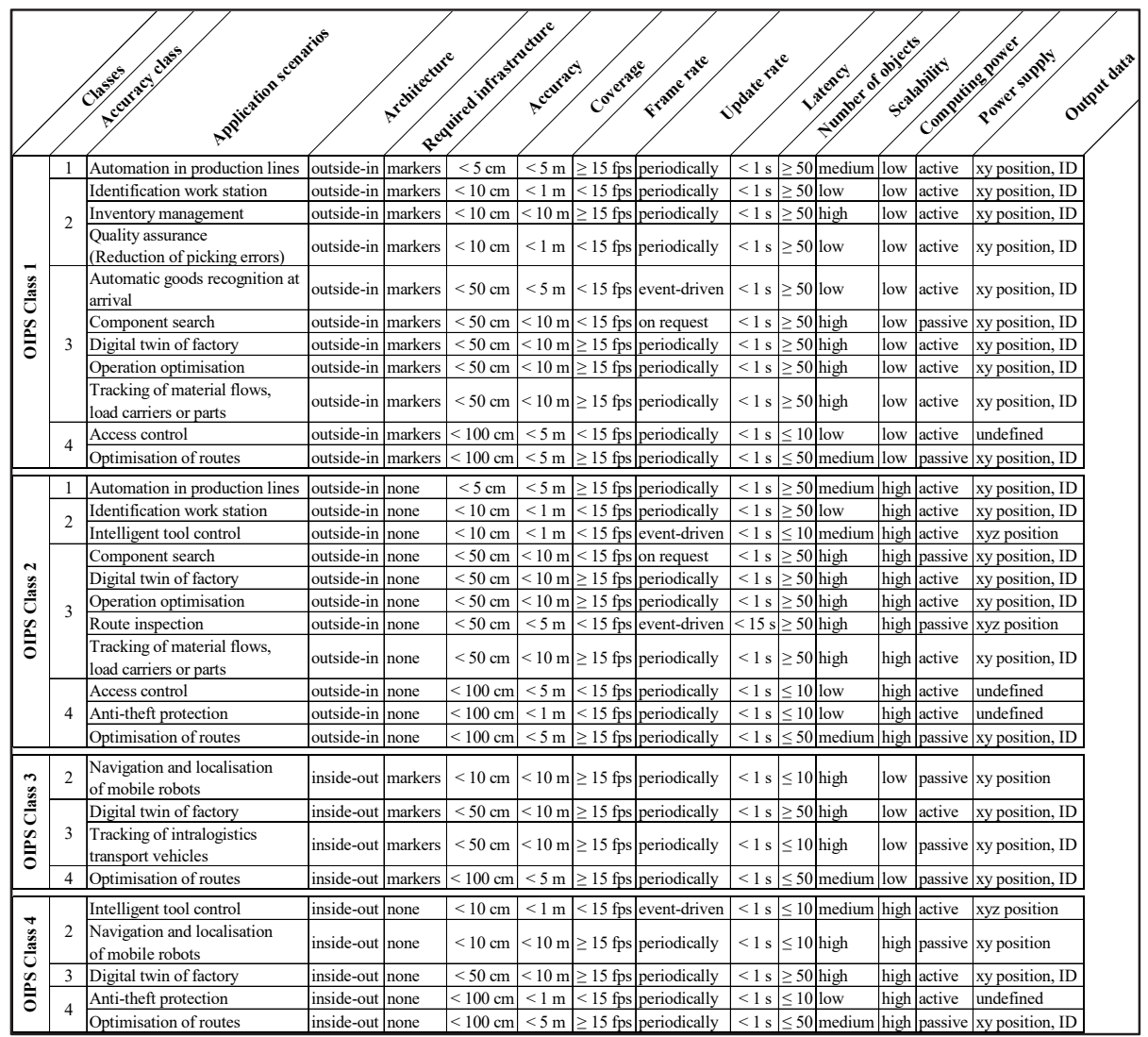

Fig. 2. Optical indoor positioning system (OIPS)-application scenarios and their characteristics

\section{References}

1. Bauernhansl, T.: Industrie 4.0 Entwicklungsfelder für den Mittelstand. Institut für Produktionstechnik und Automatisierung (Fraunhofer IPA), Stuttgart, 2016.

2. Zillmann, M.: Smart Factory - Wie die Digitalisierung Fabriken verändert: Transformation von der Werkshalle bis zur Unternehmensleitung. Mindelheim, 2016.

3. Bauernhansl, T., ten Hompel, M., Vogel-Heuser, B.: Industrie 4.0 in Produktion, Automatisierung und Logistik. Wiesbaden: Springer Vieweg, 2014. 
4. Westkämper, E.: Zukunftsperspektiven der digitalen Produktion. In: Westkämper, Spath, Constantinescu (eds.) Digitale Produktion, Springer Heidelberg, 2013.

5. Westkämper, E.: Integration in der digitalen Produktion In: Westkämper, Spath, Constantinescu (eds.) Digitale Produktion, Springer Heidelberg, 2013.

6. Hohenstein, F.C.: Systementwurf und Umsetzung einer funktionsintegrierenden Gabelstaplerlokalisierung für eine wandlungsfähige und effiziente Transportausführung. Disseration, Technische Universität München, Garching, 2014.

7. Malik, A.: RTLS for dummies. Hoboken, N.J: Wiley, 2009.

8. Youssef, M.: Indoor Localization. In Shekhar, Xiong, Zhou (eds.): Encyclopedia of GIS. Springer International Publishing, 2017, pp. 1004-1010.

9. Sakpere, W. Adeyeye Oshin, M., Mlitwa, N. B. W.: A State-of-the-Art Survey of Indoor Positioning and Navigation Systems and Technologies. SACJ, vol. 29, no. 3, 2017.

10. Lymberopoulos D. et al.: A realistic evaluation and comparison of indoor location technologies. In: IPSN '15. Seattle, Washington, 2015, pp. 178-189.

11. Brena, R. F. et al.: Evolution of Indoor Positioning Technologies: A Survey. Journal of Sensors, vol. 2017, no. 6, article 359, pp. 1-21, 2017.

12. Bubeck, A. et.al.: Vom fahrerlosen Transportsystem zur intelligenten mobilen. In: Bauernhansl, T. et.al. (eds.): Industrie 4.0 in Produktion. Wiesbaden: Springer Vieweg, 2014.

13. Klopschitz, M. et.al: Visual tracking for Augmented Reality. In: International Conference on Indoor Positioning and Indoor Navigation, Zurich, Switzerland, 2010, pp. 1-4.

14. Mautz, Tilch, S.: Survey of optical indoor positioning systems. Guimaraes, Portugal, 2011.

15. Essati, A.: Staplerortung und -navigation. IT Logistics, no. 1, pp. 38-39, 2013.

16. TotalTrax: Vehicle Tracking and Fleet Management. [Online] Available: http://www.totaltraxinc.com/smart-forklift-solutions/the-sky-trax-system/. Accessed on: Dec. 122018.

17. Logivations, Ed.: Kamerabasierte Objekterkennung. [Online] https://www.logivations.com/ de/land/pdf/KameraBasierte Objekterkennung.pdf. Accessed on: Dec. 122018

18. Mautz, R.: Indoor positioning technologies. Habilitation, ETH Zurich, 2012.

19. Günthner, W. A., Hohenstein, F.: Anforderungen und Fähigkeiten gegenwärtiger Stapler Lokalisierung. Göttingen: Vandenhoeck \& Ruprecht, 2012, pp. 17-124.

20. Liu, H. et.al.: Survey of Wireless Indoor Positioning Techniques and Systems. IEEE Trans. Syst., Man, Cybern. C, vol. 37, no. 6, pp. 1067-1080, 2007.

21. Han, G.: Development of an Indoor Location Tracking System for the Operating Room. Dissertation, Fakultät Informatik, Technische Universität München, München, 2015.

22. Zhang, H. et.al.: Localization and navigation using QR code for mobile robot in indoor environment. In: 2015 IEEE International Conference ROBIO, Zhuhai, 2015, pp. 2501-2506.

23. Tilch, S., Mautz, R.: CLIPS - a camera and laser-based indoor positioning system. Journal of Location Based Services, vol. 7, no. 1, pp. 3-22, 2013.

24. Zsifkovits, H. E., Altendorfer-Kaiser, S. (eds.): Management logistischer Informationsflüsse. Mering: Rainer Hampp Verlag, 2015.

25. Pelka, M.: (Indoor)-Lokalisation. [Online] Available: https://docplayer.org/26329710-Indoor-lokalisation.html.

26. Siemens AG: Real-Time Locating Systems (RTLS) in der Produktion: Für ein digitales Unternehmen in Bewegung. White Paper, 2018.

27. Schmidt, D.: GeoCEP - RTLS und GIS unterstütztes Event Processing. In: Strobl, J. (eds.): Angewandte Geoinformatik 2011. Berlin, Wichmann, 2011.

28. BeSpoon, Use Case Fabrik: Bringen Sie Intralogistik auf die nächste Stufe. [Online] Available: http://bespoon.com/de/zoom-on-2/fabrik/. Accessed on: Dec. 122018.

29. Lachmann, J.: Indoor / Outdoor Lokalisierung - Anwendungsbeispiele. [Online] https://www.infsoft.com/de/anwendungsbeispiele. Accessed on: Dec. 122018. 